\title{
Employing a visual representation technique to understand undergraduates' perceptions of civic engagement across countries
}

\author{
Sharon Feeney \\ Technological University Dublin, sharon.feeney@tudublin.ie \\ John Hogan \\ Technological University Dublin, john.hogan@tudublin.ie
}

Follow this and additional works at: https://arrow.tudublin.ie/buschgraart

Part of the Business Analytics Commons, Business and Corporate Communications Commons, and the Education Commons

\section{Recommended Citation}

Feeney, S. and Hogan, J. (2020), "Employing a visual representation technique to understand undergraduates' perceptions of civic engagement across countries", Journal of International Education in Business, Vol. 13 No. 2, pp. 163-182. https://doi.org/10.1108/JIEB-11-2019-0049

This Article is brought to you for free and open access by the Graduate Business School at ARROW@TU Dublin. It has been accepted for inclusion in Articles by an authorized administrator of ARROW@TU Dublin. For more information, please contact arrow.admin@tudublin.ie, aisling.coyne@tudublin.ie,gerard.connolly@tudublin.ie. 


\section{Employing a visual representation technique to understand undergraduates' perceptions of civic engagement across countries}

\author{
Sharon Feeney and John Hogan \\ College of Business, Technological University Dublin, Dublin, Ireland
}

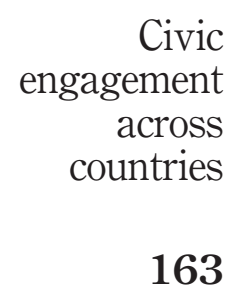

Received 15 November 2019 Revised 5 April 2020 Accepted 6 April 2020

\begin{abstract}
Purpose - This paper aims to present an interpretation of freehand drawings produced by a sample of final year degree level learners in response to the question: "What is civic engagement"? The aim in using this approach, with final year degree learners from different countries, but pursuing the same degree, was to compare and contrast their understanding of civic engagement.

Design/methodology/approach - Learners completed their drawings and then discussed their drawings in small groups. All of their drawings were initially examined quantitatively before a sample of six drawings were selected for in-depth qualitative examination.

Findings - Using learner-generated drawings enables learners convey visually what can be challenging to verbalise. After the exercise, some learners discovered that they had a good basic appreciation of civic engagement.

Research limitations/implications - Describing civic engagement pictorially forced participants to think about what the essence of civic engagement was for them.

Originality/value - This study shows how a collaborative learning experience, rather than a competitive comparison of performance, facilitates learners readily demonstrating their level of understanding and appreciation for civic engagement.
\end{abstract}

Keywords Interpretation, Civic engagement, Critical pedagogy, Drawing, Freehand, Learner-centred

Paper type Research paper

\title{
Introduction
}

Here, we examine and compare what Irish and Egyptian learners consider civic engagement to mean through freehand drawings. As there is no agreed definition of civic engagement we take it to mean "ways in which citizens participate in the life of a community to improve conditions for others or to help shape the community's future" (Adler and Goggin, 2005, p. 236). The participants are comparable as they are final year learners pursuing the same degree (business and management), awarded by an Irish university.

Freehand drawing, as a visual elicitation technique, permits learners to grasp that there are potentially multiple ways to understand, analyse and challenge any issue (Feeney, Hogan and Donnelly, 2015). Consequently, the drawing exercise serves as a useful aid to facilitate learners' conceptualisation of their understanding of the topic and permits us to examine their output. In addition, the drawing exercise and the subsequent discussion of themes and meanings, are helpful in raising learners' awareness of civic engagement.

Using learner-generated drawings provides insights into their perceptions (Donnelly and Hogan, 2013). This approach is not hindered by a lack of verbal reasoning, vocabulary,

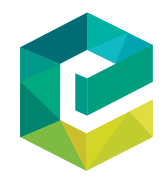

Journal of International Education in Business Vol. 13 No. 2,2020 pp. $163-182$ 
JIEB

13,2

language or inhibitions regarding differences of opinion or national identities (Meyer, 1991). The intention in using this approach was to initiate a learner-centred situation that enabled them to use a more active, self-managed and critically reflexive stance (Rose, 2008), the outputs of which could be discussed, compared and contrasted.

\section{Participant selection}

Comparative analysis has a long history in the social sciences (Mahoney and Rueschemeyer, 2003). By conducting a comparative study, we are seeking to add to the extant literature on freehand drawing as a teaching method that can stimulate a critical stance (Donnelly and Hogan, 2013) and to that on civic engagement, which largely consists of single country examinations (Feeney and Hogan, 2019; Flanagan and Levine, 2010).

Learners were attending universities in Ireland and in Egypt. The Irish university has a student body of almost 30,000 and can trace its origins to the 19th century, whereas the Egyptian university was established in 2006 and has 10,000 students. Ireland and Egypt are very different countries; Ireland has long been a free society, whereas Egypt is not; with Freedom House in 2017 scoring Ireland 96 and Egypt 26 out of 100 points [1]. Despite these differences, the participants were pursuing the same degree in business and management, both being accredited and awarded by the Irish university.

\section{Civic engagement in Irish and Egyptian higher education}

Civic engagement and active citizenship emerged as important issues in the European Union in the past two decades (Moro, 2012). The catalysts for this change was a series of policy initiatives to create a single European Higher Education Area (Feeney, 2014; Feeney and Horan, 2015); an European Research Area (Commission of the European Communities, 2000); and an European Area of Lifelong Learning (Prague Communiqué, 2001). This has been reinforced by higher education institutions (HEIs) recognising that their role goes beyond the creation of the next generation of workers and includes a wider responsibility for cultural, social and civic development (European University Association (EUA), 2002; Biesta, 2009).

In Ireland, in 2007, a "Taskforce on Active Citizenship" was established with the goal of "advising the government on the steps that [could] be taken to ensure that the wealth of civic spirit and active participation already present in Ireland continue[d] to grow and develop" (Taskforce on Active Citizenship, 2007). An Active Citizenship Office, under the aegis of the Department of the Taoiseach, was established in 2007 (McIvor, 2016). However, this initiative stalled in 2008 as Ireland fell into an economic crisis (Feeney et al., 2015, p. 314). Nonetheless, HEIs continued to expand their provision of community-based modules, to increase their links with social and cultural non-governmental organisations, as well as state-funded initiatives in the voluntary and community sector (Quillinan et al., 2018).

In Egypt, prior to the Arab Spring, political rights and civil liberties were defined and controlled by the state's apparatus, limiting the participation of citizens (Dorio, 2017). The civic engagement occurred outside the formal channels sanctioned by the state, with youth participation ranging from schools and family to the public arena (Alhamad, 2008). Various Egyptian Governments have seen education as a means of fostering the skills to become active citizens and participate in building society (Aly, 2017). In 2009, only 5\% of the Egyptian population reported volunteering, however, more sought to volunteer in mosques and churches, suggesting a growing influence of religion on volunteer practices (HaskiLeventhal et al., 2016).

Following the 2011 revolution, the Ministry of Education devoted more attention to the content of citizenship education in schools and universities (Aly, 2017). The first Egyptian 
national workshop to launch a community of practice around university-community engagement in 2013 (Garcia et al., 2017).

Civic engagement across

Guided group discussion

This study was conducted using a guided group discussion. This is because such an approach advances reflection, position-taking and critical collective sense-making. Guided discussions involve a group of people, coming together to discuss a specific issue (Schultz et al., 2011). A guided group discussion is a group conversation with a purpose.

The role of the lecturer is to facilitate the discussion to ensure that desirable attitudes and behaviours are encouraged. The lecturer seeks to strategically engage with and instruct the learners in, classroom conversation while deepening their understanding of the content considered (Walsh and Sattes, 2015). This sees a redefining of the roles and responsibilities of faculty and learners, requiring that faculty invert their self-understanding as educators (Barnett, 1997, p. 112), moving from "sage on the stage" to essentially "guide on the side". For learners, it means assuming responsibility for their learning.

Affording students the space to develop a critical disposition provides them with the opportunity to consider where civic engagement comes from, how it is structured and what social functions it serves (Reynolds, 1999). If the learners are to become adept at questioning assumptions, then they need to be exposed to critical expositions on topics. With faculty and learners, in the guided discussion context, recognising the contestability of all knowledge claims, a learning space can be created.

This is an environment that encourages learners to engage in a critical commentary (Dehler, Welsh and Lewis, 2004), which can produce a more open and creative intellectual environment (Allison et al., 2012). The resultant dialogue, breaking the traditional classroom silence, permits the development of critical consciousness among learners (Freire, 1974). Raab's (1997) "expert in not knowing" sees the role of faculty move from imparting knowledge to encouraging learners to rely on their own knowledge and experience as they endeavour to acquire more of each, thereby creating space to engage in critical selfreflection.

Students move from conveying an understanding of extant theories to theorising their own experience within the context of the broad array of understandings to which they are exposed. This constitutes critical collective sensemaking as members confront a topic that is somewhat confusing (Gloria and Thomas, 1996) and seeks to make order and retrospective sense of it (Weick, 1993). Thus, sensemaking is a process of collective social construction (Maitlis, 2005).

\section{The utility of visual representation}

The visual has assumed a culturally central position in the modern world (Slutskaya et al., 2012). Consequently, visual representation occupies a "central role in promoting and facilitating the formation, reflection and inflection of what we "take for granted" about the world" (Slutskaya, Simpson and Hughes, 2012, p. 17). However, despite its ubiquity, the visual is still largely missing from the university classroom.

Using visual techniques encourages a more vibrant exploration of a phenomenon and also challenges conventional wisdom (Parker, 2009). It functions as "a catalyst, helping them [learners] to articulate feelings that had been implicit and were hard to define" (Zuboff, 1988, p. 141), raises participants' voices through allowing them to set the agenda and own the discussion (Warren, 2005) and creates a "third space" in the room (Parker, 2009). 
Visual methods can help learners access information and sometimes even previously unrecognized insights and embodied and tacit knowledge of their relational and situated experiences (Butler-Kisber and Poldma, 2010). Drawings encourage active participation in the learning process and the integration of visual with verbal data provides a useful form of data triangulation (Flick, 2018). Where a professor would prefer not to impose a cognitive framework on learners the use of visual instruments seems ideal (Meyer, 1991, p. 232).

\section{Using drawings as critical pedagogy}

Arts-based learning presents a more holistic way of understanding the world than "the traditional tools of logic and rationality" (Page and Gaggiotti, 2012, p. 74) or what Heron and Reason (1997) refer to as "propositional knowledge".

Drawing has been of interest to psychologists for over a century. Most studies on the use of drawings focus on understanding the behavioural patterns of children and as a way of providing for observations and questions (Thomas and Jolley, 1984; Brooks, 2004). In recent years, drawings are being used as a method of data collection (Brooks, 2004; Merriman and Guerin, 2006; Gernhardt et al., 2015); and a pedagogic tool (Donnelly and Hogan, 2013). Page and Gaggiotti (2012, p. 74) proffer that visual representation "offers a relatively new medium for critical inquiry that accesses modalities of knowing that are sensory, aesthetic, affective, embodied and that cannot be reduced to the propositional".

Therefore, the visual, hand drawing, can constitute part of critical pedagogy and in the process generate critical thinking. Critical pedagogy is context-specific and descriptive, it critically analyses the world in which we live (Monchinski, 2008, p. 2). For Giroux (1997), critical pedagogy is purposely transformational, as it adopts the position that teaching and learning are dedicated to broadening the possibilities for learners. We wish to offer learners, through freehand drawing, an educational experience that challenges them to develop their own critical stances and to subsequently express their views in group discussions (Barnett, 1997).

\section{Creating the drawings}

The drawings were collected from final year learners in Ireland and Egypt. Their course was selected to examine the understanding of civic engagement amongst learners pursuing the same degree programme but in different countries. While previous research using visual techniques examined the creative products of young children in a country or across countries, we engage with two distinct groups of adult learners from different countries, bound by the same university education.

The Irish class had 60 learners, while there were 50 in Egypt, giving 110 participants. Where the Irish class had a slight majority of women, the Egyptian class was overwhelmingly male, giving a gender breakdown of 45 women to 65 men. The vast majority of Irish participants were between 21 and 24 years old, while all of the Egyptian learners were between 21 and 25 years old.

A guest lecture was dedicated to the topic of "civic engagement" in November 2017 in Egypt and in January 2018 in Dublin. At the commencement of each "civic engagement" lecture, we provided learners with an A4 sheet of paper, with instructions on one side stating: "Through a drawing answer the following question: What is civic engagement"? The other side said: "Now, in your own words, describe/explain what you have drawn".

We gave them $10 \mathrm{~min}$ to create their drawings. We then asked them to turn the sheet over and address the instruction on the reverse for $10 \mathrm{~min}$. Following this, the learners returned their drawings and these formed the central element of the class discussion on civic engagement. As Wittmann (2010) tells us, drawing has the advantage of fixing material; not 
only can that which is graphically preserved be referred to further but also be expanded upon, altered or reinterpreted by its creator and the observer.

Each drawing was projected on a screen and the class discussed their collective interpretation of what its creator was saying. We used a flipchart to capture their insights, prompting them to elaborate on assumptions. We spent about 1 min per drawing to keep the room energized and affixed the flipchart sheets to the classroom walls after discussing each drawing. The class concluded with a session opening the floor to reflection/discussion, asking what the exercise told us about perspectives and assumptions relating to civic engagement. As interpretive researchers, we ensured that the learners were positioned as "co-constructors of knowledge, identity and culture" (Janzen, 2008, p. 291).

At the end of each class, we discussed the possibility of using the drawings and outputs of the discussion for an academic paper. Participants were asked to indicate if they were happy for their drawings and a summary of the discussion to be used. All learners agreed, on the basis of anonymity. The study adheres to the ethical guidelines for both universities.

\section{Analysing the drawings}

There have been many qualitative and some quantitative approaches used to analyse learner-generated drawings. Wilson and Wilson's (1987) approach to analysing graphic narratives, in drawings of 8- to 12-year old children in Japan and Egypt, was based upon pictorial composition, narrative structure and thematic content, comprising 37 classifications. The Clark's drawing abilities test was used by Chen (1995) with children 7 to 12 years old in the USA and Taiwan. Hawkins (2002) studied a small group of three-yearolds drawing in sketchbooks over a number of weeks to examine their self-expression, identity and imagination. The criteria set out by Hall (2008), in a study of spontaneous drawings by a small number of five and six-year-olds in the UK, revolved around the themes of self and identity; storytelling; pattern and decoration and special interests. Gernhardt et al.'s (2015) used statistical analysis to examine the cultural perspectives of three- to sixyear-olds as expressed in drawings across a range of countries.

What interested us in Hall's (2008) work was its focus on how young children communicate through drawing. This built on the earlier work of Hawkins (2002). Self and identity refer to drawings being seen as an expression of an individual's perception of their self-image (Hall, 2008; Hawkins, 2002; Malchiodi, 1998). Storytelling refers to drawings where there is a narrative element. These drawings can depict stories from the external environment (Gardner, 1980; Hall, 2008). Pattern and decoration refer to a tendency by some children to give additional detail, shape and order to their drawings (Hall, 2008; Burkitt, 2008). Special interests refer to a drawing that includes details incorporated by a subject expert (Hall, 2008).

As this study uses non-commissioned drawing it is interpretive in nature (Hall, 2015). Here thick description (Denzin and Lincoln, 1998, p. 10) is achieved though using multiple data sources, including quantitatively recording the contents of all images, the active gathering of the individual learners' perspectives, the collective group interpretation of each of the images and our own interpretations of the images. Thus, we ended with short paragraphs on each drawing, along with what was captured on the flipchart sheets. The learners' provision of their own written explanations of their drawings allowed us to compare/contrast, and reflect upon, the individual and collective interpretations in each group. After the drawings were collected, they were initially analysed for their contents, which were recorded quantitatively in Table 1 below. Each of the images was then examined qualitatively, a sample of which are presented. 


\begin{tabular}{|c|c|c|c|c|}
\hline \multirow{5}{*}{$\begin{array}{l}\text { JIEB } \\
13,2\end{array}$} & Theme* & $\operatorname{Dublin}(n=60)$ & Alexandria $(n=50)$ & Total $(n=110)$ \\
\hline & Campaigning & 5 & 0 & 5 \\
\hline & Charity & 3 & 5 & 8 \\
\hline & Making a difference & 7 & 8 & 15 \\
\hline & Community involvement & 23 & 19 & 42 \\
\hline \multirow{5}{*}{168} & Providing employment & 2 & 7 & 9 \\
\hline & Voluntary work & 2 & 3 & 5 \\
\hline & Helping others & 7 & 5 & 12 \\
\hline & Role in society & 5 & 3 & 8 \\
\hline & Working together/co- operation & 12 & 14 & 26 \\
\hline \multirow{6}{*}{$\begin{array}{l}\text { Table } 1 . \\
\text { Themes contained } \\
\text { within the images } \\
\text { and accompanying } \\
\text { explanations } \\
(n=110)\end{array}$} & Communication & 12 & 9 & 21 \\
\hline & Discourse & 5 & 2 & 7 \\
\hline & Voting & 3 & 0 & 3 \\
\hline & CSR & 1 & 2 & 3 \\
\hline & Social responsibility & 10 & 12 & 22 \\
\hline & \multicolumn{4}{|c|}{ Note: *Some drawings contain more than one theme } \\
\hline
\end{tabular}

\section{What the drawings tell us about the participants understanding of civic engagement}

The drawings reflect the learners' personal understanding in answering the question "What is civic engagement"? In addition, the learners provided written explanations of what their drawings represent. This helped ensure that their intended message could be understood as the images were analysed. This was an important addition to the data, as it is possible to misinterpret/over-interpret drawings (Lewis and Lindsay, 2000). Our interaction with images is never neutral, as viewers we bring our own experiences, interests and prejudices to any interpretation (Hall, 2015).

In Table 1, we see the frequency with which each of the 14 themes that emerged were present in the drawings and their accompanying explanations, for each of the classes and overall. Table 1 illustrates the range of, and similarities between, the drawings in each jurisdiction. Interestingly, the themes of "community involvement", "social responsibility" and "helping others" were the most represented by both groups. While voting, corporate social responsibility (CSR), campaigning and voluntary work were least represented. Interestingly, on the initial analysis of the images, voting, campaigning and discourse, themes that would be associated with democracy, appeared in 13 of the Irish drawings while only appearing twice in the Egyptian images.

While we gathered and analysed 110 drawings, we present below a sample for illustrative purposes as per Wilson and Wilson (1987), Gernhardt et al. (2015) and Hall (2015). This sample, three drawings from each of the classes, is representative of the ideas emanating from the learners in Ireland and Egypt. The drawings show the learners' attempts to answer "What is civic engagement"? In what we consider primarily a "storytelling approach" (Hall, 2008); although some drawings exhibit detailing and might incorporate elements of the "pattern and decoration approach".

Using a sample of the participants' drawings and seeing them as emblematic of the wider pool, raises questions about the generalisability of findings (Dean, 2015), especially from different countries. Each of the drawings presented below is followed by our description, the written narrative provided by the learner as an explanation of their illustration and the collective interpretation of the drawing by the class. 
Figure 1 shows a circle surrounded with six different words for the learner's understanding of civic engagement and arrows pointing in a clockwise direction. These arrows add a narrative component to the image. There is no starting or endpoint to the image, but an unambiguous direction of travel. The learner clearly understands that each of these areas of activity (employees, shareholders, suppliers, environment, partners and society) are interlinked and that all provide a cycle of activities that represent civic engagement. This is the most sparsely populated of the images presented here. There is an element of pattern to this image, an interest in the regularities in the environment (Gardner, 1980). In terms of themes, the learner sees CSR as integral to civic engagement. From Table 1, this was the only Irish drawing to touch upon CSR. This is not what we would necessarily have expected, given that CSR is a central element in the degree all of these learners are undertaking and that civic engagement is featuring as an increasingly important element within the field of CSR (Bennett, 2015). This is also one of the two drawings presented here without any figures representing people in it.

\section{Learner's narrative}

Civic engagement involves constant interaction between all stakeholders of a particular area.

\section{Collective interpretation}

This drawing generated significant interest in the class. Learners debated whether or not, all six of the elements are equally important to the cycle of a business. Many expressed the belief that "environment" and "society" should not be part of the cycle but would be better

Through a drawing answer the following question: What is Civic Engagement?

When you've drawn your picture, flip over the page and describe/ explain your drawing in your own words.

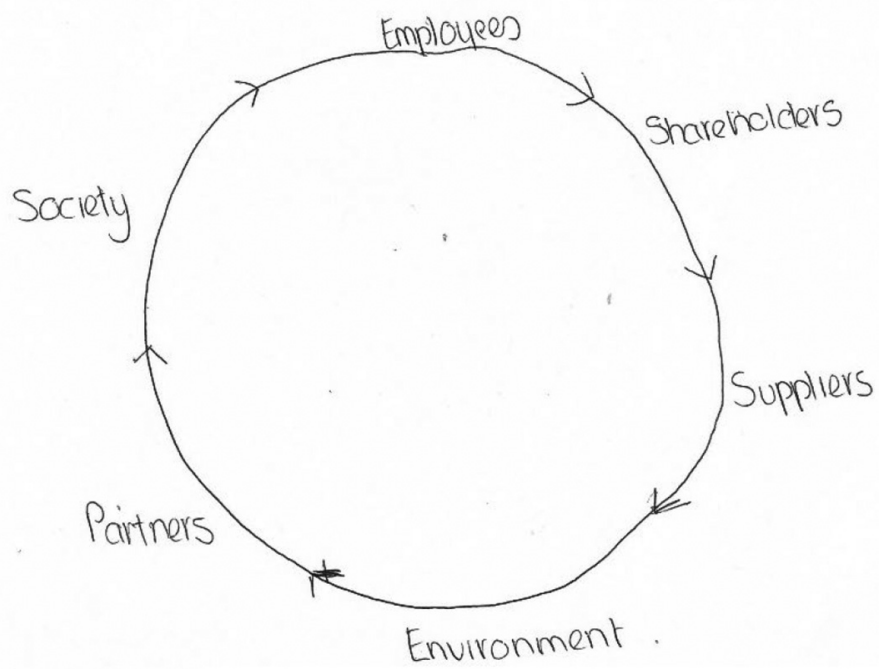

Figure 1. 
JIEB

13,2

Figure 2.

Irish learner drawing Sample 2 placed outside of it, where the business cycle would be shown to impact upon both the environment and society.

\section{Our description}

Figure 2 incorporates significant detail and depicts two figures protesting against water charges. Following Ireland's economic bailout by the international monetary fund, the European Central Bank (ECB) and the European Commission, widely referred to as the troika, in late 2010, successive governments attempted, in the face of national protests, to introduce a general water use tax, despite citizens already paying for such provisions in their taxation (Leonard, 2018). This drawing, with its narrative component, possesses a storytelling element (Hall, 2008). For Gardner (1980) this is the work of a dramatist, someone who is interested in depicting a story. The drawing shows both figures carrying placards with anti-water charges words on them and the text above the protesters saying protests $=>$ communicate. This is an interesting element in the drawing, as it shows that the learner considers protests to be a form of communication and this kind of communication constitutes a form of civic engagement. Communication was one of the more represented themes to emerge in the drawings from both countries as set out in Table 1 . There is also a slightly chaotic feel to this image and the two figures constitute what are referred to as tadpole figures. That is a drawing of a head with two vertical lines attached to it, the legs, without there being a trunk depicted (Freeman, 1980; Cox, 1993). It is an image very often produced by very young children when drawing.

\section{Learner's narrative}

A group of people coming together to share a particular message.

Collective interpretation: many learners disagreed with the drawing of political protests constituting civic engagement. They insisted that political issues did not and should not, form part of the civic engagement conversation between them. There was much disagreement about this during the class discussion.

\section{Our description}

Figure 3, with its detailed hands, exists within the storytelling approach proposed by Hall (2008). The drawing depicts joined hands with the words "for a better world" written

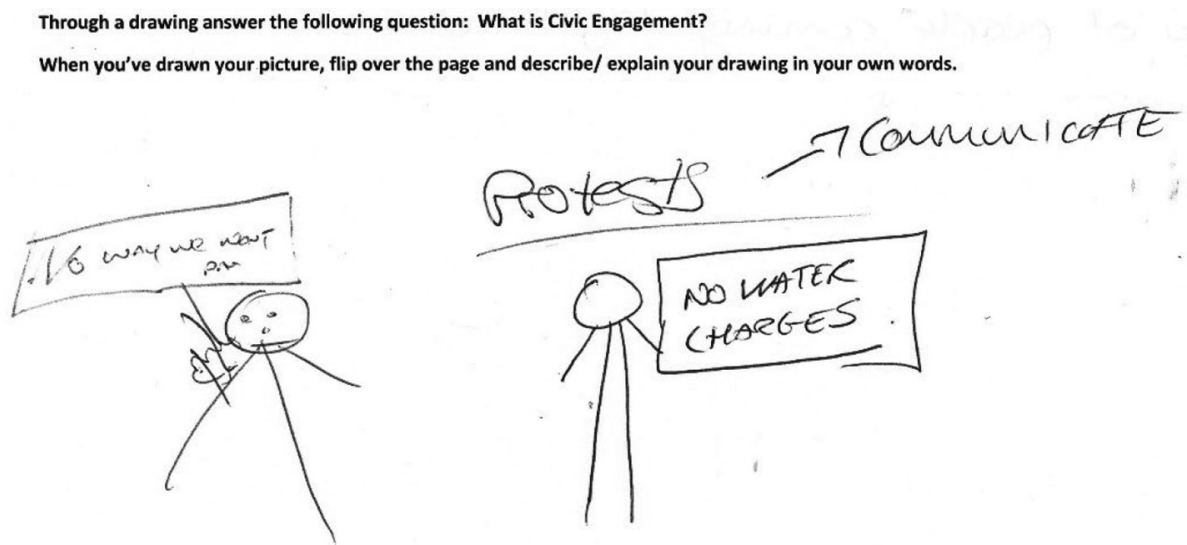




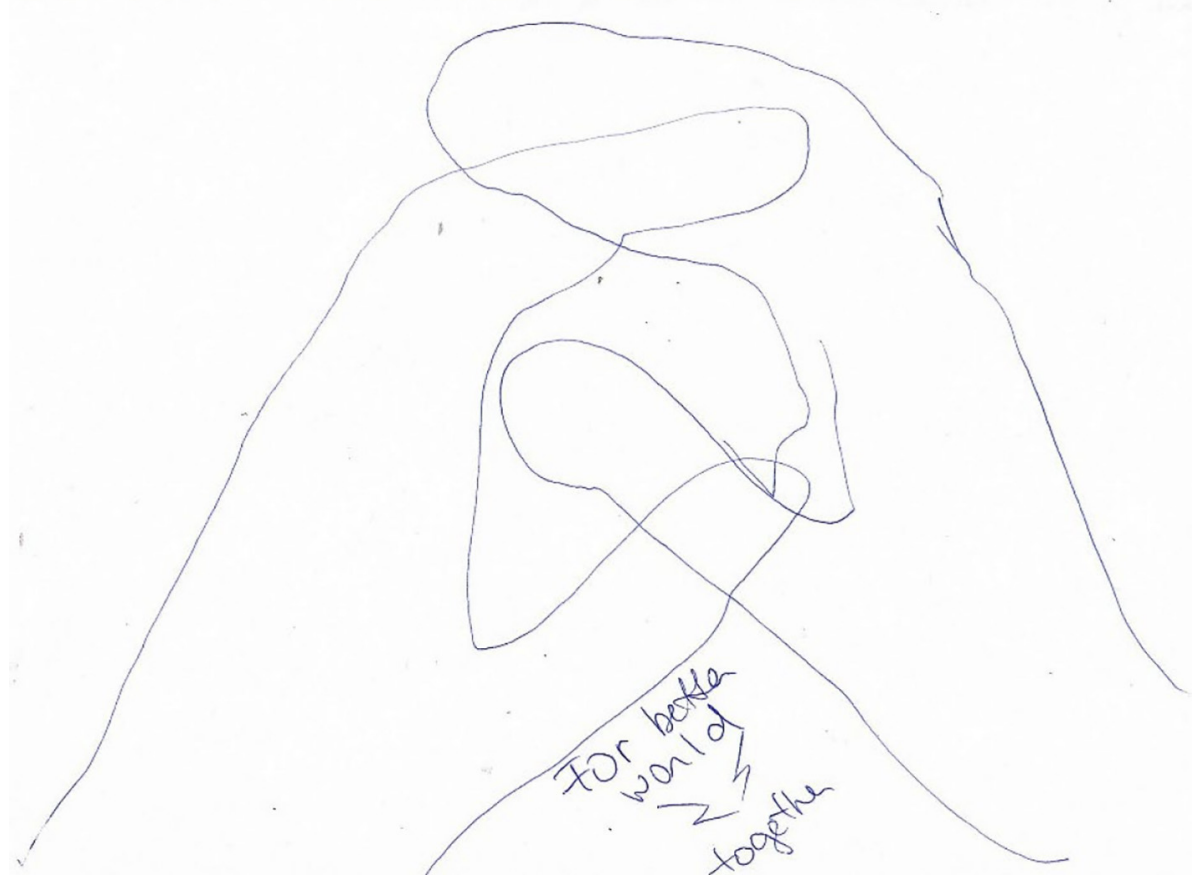
across countries

beneath them. The image is aided by the use of text to communicate its message. It is interesting that the joined hands are presented from the perspective of the observer, rising from the bottom of the page, almost as if we are being invited to look upon these hands as our own as the image draws us in. The idea that civic participation can create a better world, as it is widely considered to be at the heart of a flourishing democracy, is central to much of the literature on civic engagement (Jones et al., 2007; Bonnet, 2017). The image suggests people coming together to improve things. In Table 1, the message in this drawing comes under the themes of working together/co-operation and making a difference. Collaboration is a central element of our modern understandings of civic engagement (Hasegawa, 2010).

\section{Learner's narrative}

Mutual agreement between different people. Interactions would impact a world in a particular way. Meant to be a handshake on an agreement where we are going.

\section{Collective interpretation}

The class viewed the drawing of the hands as representing agreement and compromise. Interestingly, there was a rich discussion about the importance of reaching agreement or compromise, as part of all engagement activities, most especially in political engagement. Some learners saw the handshake as a symbol of a positive outcome of civic engagement, where true engagement leads to a compromise being reached. 
JIEB

13,2

172

\section{Egyptian learner drawings}

\section{Our description}

Figure 4 depicts significant detail, showing three different contexts for the learner's understanding of civic engagement. Again, this drawing fits within the storytelling approach, with its three-part narrative structure (Hall, 2008). The drawing starts with two people sharing something or one handing something to the other. Next, we see a figure talking to others through what looks like a screen. Finally, we see a figure watering plants. The images dominate the central third of the page, creating a series of focal points to lead our gaze around the drawing and providing places for the eye to pause and digest the message being conveyed. This is the most populated of the images presented here, with representations of human figures, containing seven in all. Brooks (2004) observes that the quality of the drawing is its generative possibilities and this drawing shows a progressive desire for societal improvement on the part of the learner. Here the themes of discourse, communication and social responsibility are present. There is also a sense of order and hierarchy to the image. From Table 1, we can see that this was only one of two Egyptian
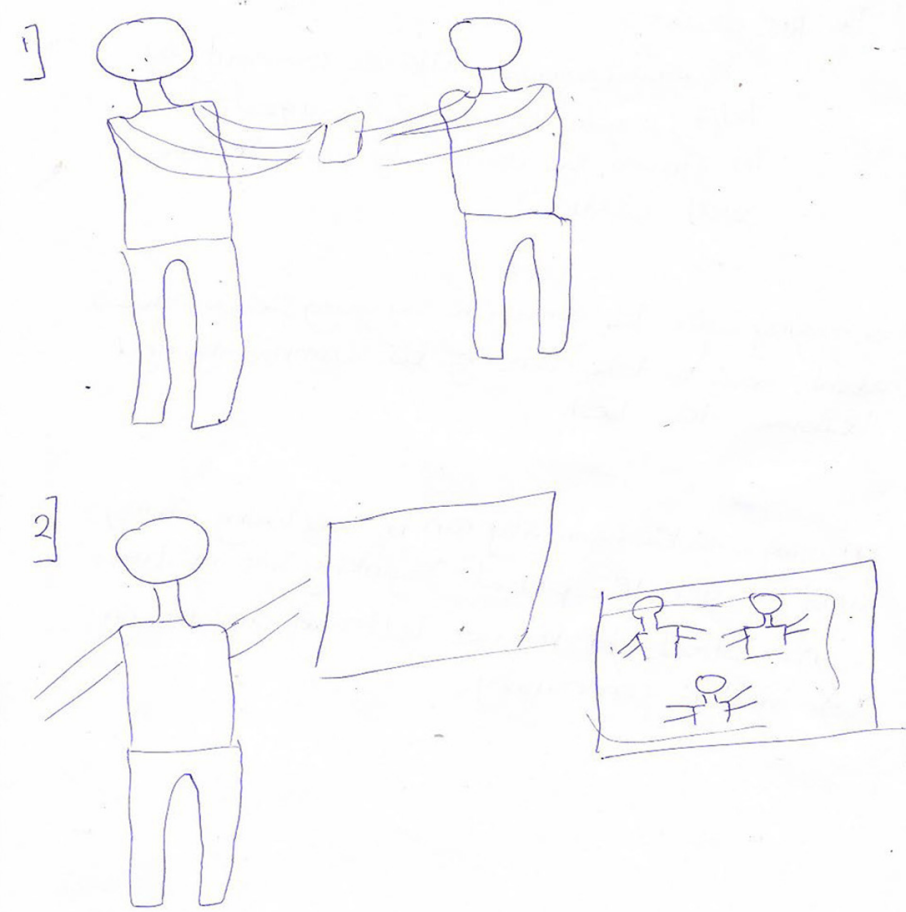

Figure 4.

Egyptian learner drawing Sample 1

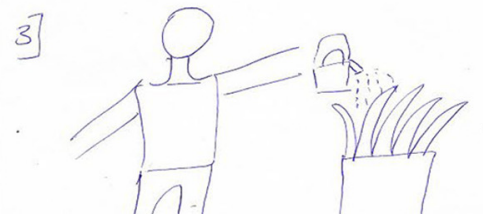


drawings to touch on the topic of discourse. The image "is immediately holistic and interactive in ways that writing is not" (Brooks, 2004, p. 49).

\section{Learner's narrative}

- The first drawing: is about engaging with the community by helping people, being helpful is a good factor in growing the community and become well civilised.

- Engaging with the community by giving people advice about how to take care of the community and become the best.

- Engaging with the community can be by being caring and saving the planet by taking care of trees and streets to become better and live in a better community.

\section{Collective interpretation}

This drawing stimulated some lengthy discussion about the equal status of helping people in the community, giving advice to the community so as to improve the life and conditions of citizens and taking care of plants and the environment to preserve nature in the community. Many learners agreed that the first picture, depicting a person helping another, is an important aspect of civic engagement. The second image, which shows someone giving advice to others, initiated a lot of discussion around the importance of enabling citizens to help themselves to effect greater change at a societal level. Finally, the third part of the drawing, which depicts caring for plants to ensure a better community, saw a lot of agreement. There was a consensus that everyone has a responsibility to protect the environment.

\section{Our description}

In Figure 5, many people (five in total) are interacting, or conversing, with one another. We recognise that the drawing has a very specific narrative for its creator, which reflects their personal observations and perceptions (Malchiodi, 1998), and thus, falls into the storytelling approach (Gardner, 1980; Hall, 2008). The layout of the drawing also suggests a sense of disorder, people interacting variously, in comparison to the order and hierarchy of the previous drawing. Interestingly, all participants are communicating in both directions, depicting that each participant is listening and speaking in a manner that suggests equality. This to and for stands in contrast also to Figure 1, with its clear arrows pointing in one direction only. This drawing enables it, creator, to communicate their "funds of knowledge" on civic engagement through the image they create (Moll et al., 1992). In Table 1, this image comes under the themes of discourse and communication. Participation in society is constructed primarily in terms of discourse and in a democratic society in terms of deliberative discourse (Locklin and Posman, 2017).

\section{Learner's narrative}

We are all in society and all people have a mission to another person and we should apply social responsibility to improve our society.

\section{Collective interpretation}

The class viewed this drawing as depicting everyone's responsibility to improve themselves and others. The discussion in class revolved around individual responsibility to be the best 

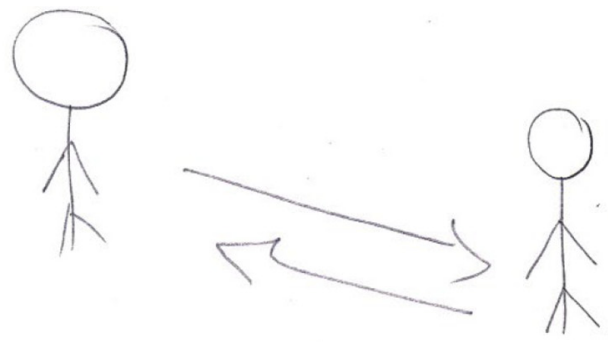

\section{Figure 5.}

Egyptian student drawing Sample 2
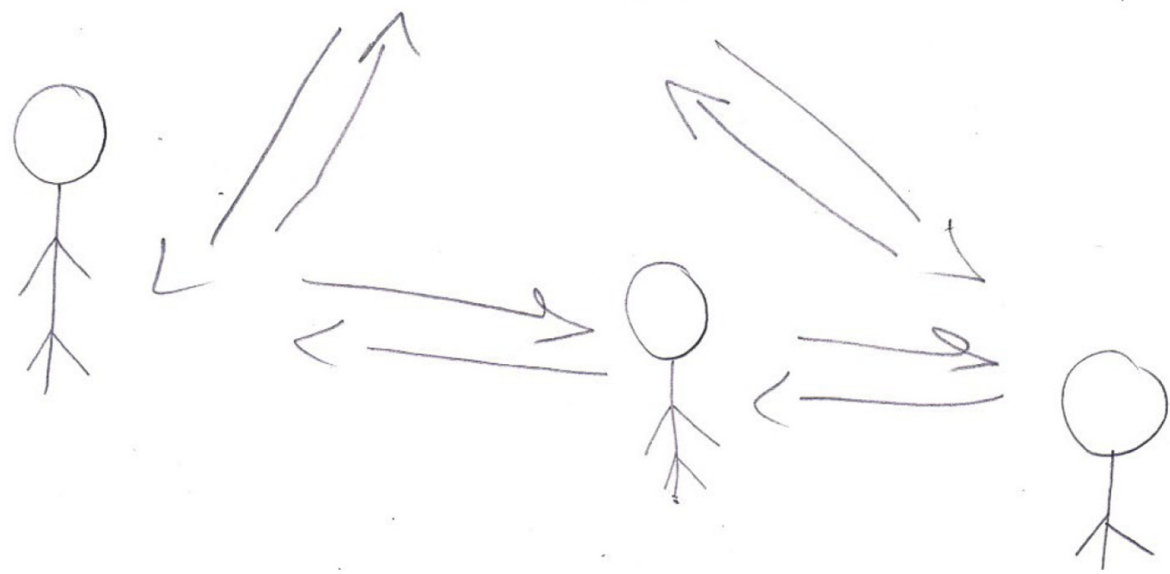

person you can be and then to develop that in others so we can all be the best we can be. By achieving this, we are accepting our civic responsibility to be active and engaged citizens.

\section{Our description}

Figure 6 incorporates significant detail and fits within Hall's (2008) storytelling approach. The drawing depicts a figure at the centre of the world and the word community above this, with joined hands positioned beneath the globe. Civic engagement is "a broad set of behaviours that link individuals together in their community and serve to enhance community life" (Pancer, 2015, p. 20). The figure here is drawn much more elaborately than any of the other figures in the other drawings presented, those being mostly tadpole figures or stick figures. This is the second image, after Figure 3, to display joined hands, though these hands are presented sideways on. There is clearly an element of drawing as a visual language emerging here (Golomb, 1992). It depicts joint responsibility at a global level for civic engagement and our connectedness to each other and to the whole world. The themes represented here are to do with one's role in society and one's social responsibility, as set out in Table 1.

\section{Learner's narrative}

I tried to draw the community, which is the whole world and I'm in that world or community I'm a part of this community involved in it [sic]. Another drawing, which is two hands are connected to each other. One is me and the other is the community, which shows that we must be connected to each other in every single thing. 


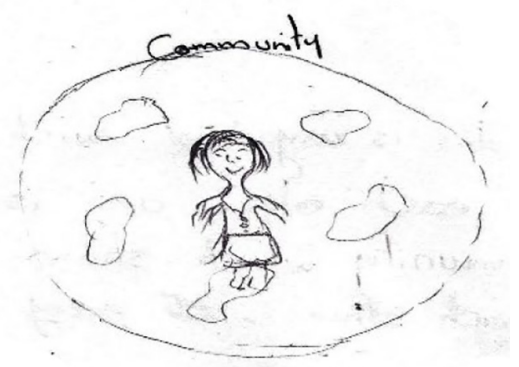

Civic engagement across countries
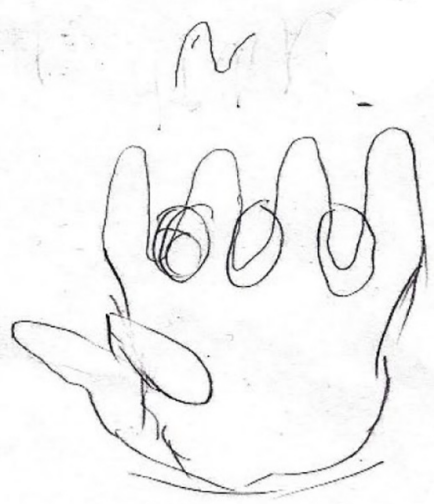

Figure 6.

Egyptian student drawing Sample 3

\section{Collective interpretation}

This drawing stimulated significant discussion in class. There was general agreement that the community can be a small group of learners in a university, a family, a neighbourhood, a city, a country, a region or the whole world. In this picture, the learner drew the whole world and themselves at the centre. By depicting themselves at the centre of the world, the learner shows their own central role in ensuring all engagement is focussed on making the world a better place. The next part of the drawing depicts joined hands, which signifies the importance of being connected to each other in everything we do. The learners generally agreed that civic engagement requires active participation, agreement and compromise in moving ideas and actions onwards.

\section{What the sampled themes and their in-class discussions told us}

Being business students, it is not surprising that CSR (Figure 1) was mentioned as a form of civic engagement. What was surprising was that it appeared so few times in the drawings (Table 1). During the in-class discussion, CSR drew a lot of attention, as it is an issue that the learners are familiar with. Communication between citizens and their government (Figures 2, 4 and 5) and discourse between each other (Figures 4 and 5) was seen as a form of civic engagement. The learners in the in-class discussion felt that communications and discourse were central to civic engagement, which is interesting in that communications appeared in 21 drawings while discourse only appeared in 7 (Table 1). However, somewhat 
JIEB

13,2

contradictory, there was disagreement among the Irish learners as to whether political protests constituted civic engagement. Working together/cooperation and helping others (Figures 3 and 4) were regarded as important aspects of civic engagement and appeared in 26 drawings (Table 1). The topic of social responsibility (Figures 4 and 6) came up a lot in the discussion, with almost universal agreement that preserving the environment is central to civic engagement, social responsibility appeared in 22 drawings (Table 1). As Hall (2015) found with children's drawings, the drawings cannot be fully understood as presented on paper, as their creators sometimes mentioned additional elements or objects, in their narratives that lay outside of the actual images they produced.

Although often basic and superficial, when we pressed the learners in their interpretation of their drawings during the in-class discussion, they began to recognize and query their own and others', conjectures. There is a narrative journey taken in discussing the drawings, where the drawings constitute a narrative springboard (Wright, 2007). Examining drawings, through discursive interaction, highlights the complexity and creates the possibility of richer thinking and expression (Davison, McLean and Warren, 2012, p. 8), "where students can challenge prevailing assumptions" (Smith, 2003, p. 21). "By facilitating and holding a safe, listening space, the researcher enables the participant(s) to story, narrate or dialogue with the image(s), thus allowing layers of meanings and significance to emerge" (Leitch, 2008, p. 54). Our approach of image production, followed by guided group discussion, can promote reflexive engagement to produce varied viewpoints as we ensure that all voices are heard and not just those who dominate classroom discussion, thus enabling their multiple voices to be better represented/performed through the technique of "native image-making" (Warren, 2005, p. 861). In allowing learners convey visually what can be challenging to verbalise, drawings permit us to participate in a dialectical interaction wherein we can complicate their understanding and develop their aptitude for critical selfreflection. Thus, freehand drawing helps to empower and emancipate students whose unique insights might otherwise be silenced or hidden.

After the exercise, some learners discovered that they had a good basic appreciation of civic engagement. However, many still could not understand the significance of civic engagement. Clearly, learners had an interpretation of what civic engagement means but struggled when trying to contextualise that meaning into everyday social and civic experience, particularly at the level of individual responsibility. Nevertheless, they recognised that by cooperating in critically examining each other's drawings, they were able to identify aspects of, and nuances in, their understanding.

\section{Pedagogical and policy implications}

There are numerous ways in which the higher education curriculum in Ireland has provided learners with opportunities for their moral and civic development. Service-learning and learning in the community have provided some of these learning opportunities. This is in contrast to Egypt, where community links are still in the early stages of development for HEIs. However, since 2011, Egypt has experienced rapid growth in university/community engagement projects (Garcia, Cook and View, 2017).

Freehand drawing, in encouraging learners to reflect critically, contributes to developing the kind of engaged citizenry vital for a flourishing democracy. The approach also surmounts the long-term bias in instructional pedagogies towards oversimplification (Dehler et al., 2004, p. 168) and the favouring of propositional knowledge (Heron and Reason, 1997), as it allows learners to appreciate that there are many ways to comprehend, contest and analyse issues. The use of freehand drawing is intended to address the calls by Bartunek et al. (1983) for "developing complicated understanding" and by Dehler et al. (2004) 
for "creating richer complexities" in critical thinking that serve to question what is presented as "the one true way" (Stepanovich, 2009, p. 726).

The principles of best practice for a pedagogy of civic engagement include active learning, learning as a social process, contextual knowledge, reflexive practice and the ability to represent an idea in a variety of contexts (Welch, 2007). The traditional approach is classroom-based lectures and focussed upon the development of personally responsible citizens, while the alternative is a service-learning model emphasising a justice-oriented conception of citizenship (DeLaet, 2015). In this respect, the use of images possesses great value, as they have the potential to economically encode significant quantities of complex information (Ridley and Rogers, 2010). In seeking to create a space for nuance and ambiguity in the classroom using drawings, we complicate learners' understanding through moving away from certainty towards an acceptance of ambiguity and paradox, complexity rather than simplicity (Zohar, 1997).

\section{Conclusion}

Using freehand drawing to promote a dialectical exchange with learners about civic engagement - to cultivate their capacity for critical self-reflection - allows them to put into visuals a level of comprehension, that is, sometimes difficult to articulate verbally. The presentation of information visually can enable learners to access unrecognised insights and make sense of complex issues by using a whole-brain approach. Learners, using the higherorder thinking integral to visualisation, can define their knowledge of a topic that is universally understandable and rich in content.

That the learners discuss the drawings as a group, in which every voice is heard, encourages interpretations from multiple perspectives and gives learners and professors an opportunity to challenge theories, presumptions and beliefs. This approach can raise questions about what is being viewed and aids reflection on the wider context. The objective of such critical pedagogies should be to produce questioning citizens capable of selfreflection and willing to question widely held beliefs.

Our aim in using this approach, with final year degree learners from different countries, but pursuing the same degree, was to compare and contrast their understanding of civic engagement. All of their drawings were initially examined quantitatively before a sample of six were presented.

An element of national difference was evident under the headings of campaigning, discourse and voting in Table 1 . In total, 13 Irish drawings contained these themes, whereas only 2 Egyptian drawings did. This is not that surprising given the very different democratic histories of both countries. We found that all of the drawings $(n=110)$ were similar in using a narrative approach. However, we are story-telling animals that like familiar patterns/narratives that we can easily understand (Shermer, 2002). Five of the six drawings examined in detail involved communication and/or a cyclical approach to understanding civic engagement. All of the learners understood that civic engagement involves other people and the need to co-operate.

Many implications can be identified from this study. Describing civic engagement pictorially forced participants to think about what the essence of civic engagement was for them. The 110 images produced, their themes compiled in Table 1 and the sampled six drawings discussed in detail, all show that the learners possessed a significant amount of knowledge and understanding of civic engagement. With Waltz (1979) defining theory as a picture that is mentally formed of a bounded realm, the learners were, through their drawings, creating their own theories of civic engagement. By both producing and observing their own drawings the learners were positioned in a way they were 
unaccustomed to in the classroom - as creators of and critically reflecting on knowledge. This study shows how a collaborative learning experience, rather than a competitive comparison of performance, facilitates learners readily demonstrating their level of understanding and appreciation for civic engagement.

\section{Note}

1. https://freedomhouse.org/report/freedom-world/freedom-world-2017

\section{References}

Adler, R.P. and Goggin, J. (2005), "What do we mean by civic engagement?", Journal of Transformative Education, Vol. 3 No. 3, pp. 236-253.

Alhamad, L. (2008), "Formal and informal venues of engagement", in Lust-Okar, E. and Zerhouini, S. (Eds), Political Participation in the Middle East, Lynne Rienner, CO, pp. 33-48.

Allison, P., Carr, D. and Meldrum, G. (2012), "Potential for excellence: interdisciplinary learning outdoors as a moral enterprise", The Curriculum Journal, Vol. 23 No. 1, pp. 43-58.

Aly, S. (2017), "Citizenship education: a critical content analysis of the Egyptian citizenship education textbooks after the revolution", in Megahed, N. (Ed.), Education during the Time of the Revolution in Egypt: Dialectics of Education in Conflict, Sense Publishers, Rotterdam, pp. 59-79.

Barnett, R. (1997), Higher Education: A Critical Business, The Society for Research into Higher Education and Open University Press, Bristol, PA.

Bartunek, J.M., Gordon, J.R. and Weathersby, R.P. (1983), "Developing 'complicated' understanding in administrators", Academy of Management Review, Vol. 8, pp. 273-284.

Bennett, W.L. (2015), "Foreword", in Uldam, J. and Vestergaard, A. (Eds), Civic Engagement and Social Media: Political Participation beyond Protests, Palgrave Macmillan, Basingstoke, pp. 8-23.

Biesta, G. (2009), "What kind of citizenship for European higher education? Beyond the competent active citizen", European Educational Research Journal, Vol. 8 No. 2, pp. 146-158.

Bonnet, J. (2017), “Citizenship”, in Komives, S.R. and Wagner, W. (Eds), Leadership for a Better World: Understanding the Social Change Model of Leadership Development, John Wiley and Sons, San Francisco, pp. 175-190.

Brooks, M. (2004), "Drawing: the social construction of knowledge", Australasian Journal of Early Childhood, Vol. 29 No. 2, pp. 41-49.

Burkitt, E. (2008), “Children's choice of color to depict metaphorical and affective information”, in Milbrath, C. and Trautner, H.M. (Eds), Children's Understanding and Production of Pictures, Drawings, and Art, Hogrefe and Huber, Cambridge, MA, pp. 107-120.

Butler-Kisber, L. and Poldma, T. (2010), "The power of visual approaches in qualitative inquiry: the use of collage making and concept mapping in experiential research", Journal of Research Practice, Vol. 6 No. 2, pp. 1-16.

Chen, L.-T. (1995), "A critical examination of cultural influences on children's drawings from the midWestern United States and Taiwan", Marilyn Zurmuehlen Working Papers in Art Education, Vol. 13 No. 1, pp. 13-19.

Commission of the European Communities (2000), "Towards a European research area. Communication from the commission to the council, the European parliament, the economic and social committee and the committee of the regions", Com, 6, Commission of the European Communities, Brussels.

Cox, M.V. (1993), Children's Drawings of the Human Figure, Psychology Press, Hove. 
Davison, J., McLean, C. and Warren, S. (2012), "Exploring the visual in organizations and management", Qualitative Research in Organizations and Management: An International Journal, Vol. 7 No. 1, pp. 5-15.

Dean, J. (2015), "Drawing what homelessness looks like: using creative visual methods as a tool of critical pedagogy", Sociological Research Online, Vol. 20 No. 1, available at: www.socresonline. org.uk/20/1/2.html (accessed 2 February 2020).

Dehler, G., Welsh, A. and Lewis, M. (2004), "Critical pedagogy in the "new paradigm": raising complicated understanding in management learning", in Grey, C. and Antonacopoulou, E. (Eds), Essential Readings in Management Learning, Sage, London, pp. 167-186.

DeLaet, D.L. (2015), “A pedagogy of civic engagement for the undergraduate political science classroom", Journal of Political Science Education, Vol. 12 No. 1, pp. 72-84.

Denzin, N.K. and Lincoln, Y.S. (Eds) (1998), "Introduction: entering the field of qualitative research", in, Strategies of Qualitative Enquiry, Sage, Thousand Oaks, CA, pp. 1-34.

Donnelly, P.F. and Hogan, J. (2013), "Engaging students in the classroom: "how can I know what I think until I see what I draw?”, European Political Science, Vol. 12 No. 3, pp. 365-383.

Dorio, J.N. (2017), "The revolution as a critical pedagogical workshop: Perceptions of university students reimagining participatory citizenship(s) in Egypt", in Megahed, N. (Ed.), Education during the Time of the Revolution in Egypt: Dialectics of Education in Conflict, Sense Publishers, Rotterdam, pp. 11-37.

European University Association. (EUA) (2002), Universities as the Motor for the Construction of a Europe of Knowledge, Input to the Barcelona Summit, EUA, Brussels.

Feeney, S. (2014), "Institutional quality review in higher education in the republic of Ireland and Northern Ireland: a comparison of two approaches", Doctoral thesis, University of Sheffield, Sheffield.

Feeney, S. and Hogan, J. (2019), "Using drawings to understand perceptions of civic engagement across disciplines: 'seeing is understanding”, Politics, Vol. 39 No. 2, pp. 233-251.

Feeney, S. and Horan, C. (2015), "The bologna process and the European qualifications framework: a routines approach to understanding the emergence of educational policy harmonisation - from abstract ideas to policy implementation”, in Hogan, J. and Howlett, M. (Eds), Policy Paradigm in Theory and Practice: Discourses, Ideas and Anomalies in Public Policy Dynamics, Palgrave, Basingstoke, pp. 189-215.

Feeney, S., Hogan, J. and Donnelly, P.F. (2015), "What stick figures tell us about Irish politics: creating a critical and collaborative learning space", Teaching in Higher Education, Vol. 20 No. 3, pp. 313-327.

Flanagan, C. and Levine, P. (2010), "Civic engagement and the transition to adulthood", The Future of Children, Vol. 20 No. 1, pp. 159-179.

Flick, U. (2018), “Triangulation in data collection”, in Flick, U. (Ed.), The Sage Handbook of Qualitative Data Collection, SAGE, London, pp. 527-544.

Freeman, N.H. (1980), Strategies of Representation in Young Children: Analysis of Spatial Skills and Drawing Processes, Academic Press, London.

Freire, P. (1974), Education: The Practice of Freedom, Penguin, Harmondsworth.

Garcia, R.S., Cook, C. and View, J.L. (2017), "Universidad sin fronteras: transgressing intellectual borders and redefining learning", in Dolgon, C., Mitchell, T.D. and Eatman, T.K. (Eds), The Cambridge Handbook of Service Learning and Community Engagement, Cambridge University Press, Cambridge, pp. 193-203.

Gardner, H. (1980), Artful Scribbles: The Significance of Children's Drawings, Jill Norman, London.

Gernhardt, A., Rubeling, H. and Keller, H. (2015), “Cultural perspectives on children's tadpole drawings: at the interface between representation and production”, Frontiers in Psychology, Vol. 6 No. 1, pp. 1-10. 
Giroux, H.A. (1997), Pedagogy and the Politics of Hope: Theory, Culture, and Schooling, Westview Press, Boulder, CO.

Gloria, D.A. and Thomas, J.B. (1996), "Identity, image and issue interpretation: sensemaking during a strategic change in academia", Administrative Science Quarterly, Vol. 41 No. 3, pp. 370-403.

Golomb, C. (1992), The Child's Creation of a Pictorial World, University of CA Press, Berkley, CA.

Hall, E. (2015), "The ethics of 'using' children's drawings in research", in Stirling, E. and Yamada-Rice, D. (Eds), Visual Methods with Children and Young People. Studies in Childhood and Youth, Palgrave Macmillan, London, pp. 140-163.

Hall, E. (2008), "My brain printed it out!" drawing, communication, and young children: a discussion", Paper presented at the British Educational Research Association Annual Conference, Edinburgh, 3-6.

Hasegawa, K. (2010), “Collaborative environmentalism in Japan”, in Vinken, H., Nishimura, Y., White, B.L.J. and Deguchi, M. (Eds), Civic Engagement in Contemporary Japan: Established and Emerging Repertoires, Springer, New York, NY, pp. 85-100.

Haski-Leventhal, D., Metz, E., Hogg, E., Ibrahim, B., Smith, D.H. and Wang, L. (2016), "Volunteering in three life stages", in Smith, D.H., Stebbins, R.A. and Grotz, J. (Eds), The Palgrave Handbook of Volunteering, Palgrave, Civic Participation and Nonprofit Associations Basingstoke, London, pp. 682-702.

Hawkins, B. (2002), “Children's drawing, self-expression, identity and the imagination”, International Journal of Art and Design Education, Vol. 21 No. 3, pp. 209-219.

Heron, J. and Reason, P. (1997), “A participatory inquiry paradigm”, Qualitative Inquiry, Vol. 3 No. 3, pp. 274-294.

Janzen, M.D. (2008), "Where is the (postmodern) child in early childhood education research?", Early Years, Vol. 28 No. 3, pp. 287-298.

Jones, E., Haenfler, R. and Johnson, B. (2007), Small Changes That Make a Big Difference: The Better World Handbook, New Society Publishers, Gabriola Island.

Leitch, R. (2008), “Creatively researching children's narratives through images and drawings", in Thomson P. (Ed.), Doing Visual Research with Children and Young People, Routledge, Abingdon, pp. 37-58.

Leonard, L. (2018), The Sustainable Nation: Politics, Economy and Justice, Emerald Publishing Limited, Bingley.

Lewis, A. and Lindsay, G. (2000), "Emerging issues", in Lewis, A. and Lindsay, G. (Eds), Researching Children's Perspectives, Open University Press, Buckingham, pp. 189-197.

Locklin, R.B. and Posman, E. (2017), "Discourse, democracy and the many faces of civic engagement", in Clingerman, F. and Locklin, R.B. (Eds), Civic Engagement, Cambridge University Press, Cambridge, pp. 3-22.

McIvor, C. (2016), Migration and Performance in Contemporary Ireland, Palgrave Macmillan, Basingstoke.

Mahoney, J. and Rueschemeyer, D. (2003), "Comparative historical analysis: achievements and agendas", in Mahoney, J. Rueschemeyer, D. (Eds), Comparative Historical Analysis in the Social Sciences, Cambridge University Press, Cambridge, pp. 3-40.

Maitlis, S. (2005), "The social process of organisational sensemaking", Academy of Management Journal, Vol. 48 No. 1, pp. 21-49.

Malchiodi, C. (1998), Understanding Children’s Drawings, The Guilford Press, New York, NY.

Merriman, B. and Guerin, S. (2006), “Using children's drawings as data in child-centred research", The Irish Journal of Psychology, Vol. 27 Nos. 1/2, pp. 48-57.

Meyer, A.D. (1991), "Visual data in organizational research", Organization Science, Vol. 2 No. 2, pp. 218-236. 
Moll, L.C., Amanti, C., Neff, D. and Gonzalez, N. (1992), "Funds of knowledge: using a qualitative approach to connect homes and classrooms", Theory into Practice, Vol. 31 No. 2, pp. 132-141.

Monchinski, T. (2008), Critical Pedagogy and the Everyday Classroom, Springer, New York, NY.

Moro, G. (2012), Citizens in Europe: Civic Activism and the Community Democratic Experiment, Springer,.New York, NY.

Civic

engagement

across

countries

Page, M. and Gaggiotti, H. (2012), "A visual enquiry into ethics and change", Qualitative Research in Organizations and Management: An International Journal, Vol. 7 No. 1, pp. 72-85.

Pancer, S.M. (2015), The Psychology of Citizenship and Civic Engagement, Oxford University Press, Oxford.

Parker, L.D. (2009), "Photo-elicitation: an ethno-historical accounting and management research prospect", Accounting, Auditing and Accountability Journal, Vol. 22 No. 7, pp. 1111-1129.

Prague Communiqué (2001), "Towards the European higher education area", Communiqué of the meeting of European Ministers in charge of higher education in Prague on May 19th.

Quillinan, B., McEvoy, E., MacPhail, A. and Dempsey, C. (2018), "Lessons learned from a community engagement initiative within Irish higher education", Irish Educational Studies, Vol. 37 No. 1, pp. 112-126.

Raab, N. (1997), "Becoming an expert in not knowing: reframing teacher as a consultant", Management Learning, Vol. 28 No. 2, pp. 161-175.

Reynolds, M. (1999), "Grasping the nettle: possibilities and pitfalls of a critical management pedagogy", British Journal of Management, Vol. 10 No. 2, pp. 171-184.

Ridley, P. and Rogers, A. (2010), Drawing to Learn: Arts and Humanities, University of Brighton, Brighton.

Rose, G. (2008), Visual Methodologies: An Introduction to the Interpretation of Visual Materials, Sage, London.

Schultz, P.W., Tabanico, J.J. and Rendón, T. (2011), "Normative beliefs as agents of influence", in Crano, W.D. and Prislin, R. (Eds), Attitudes and Attitude Change, Psychology Press, New York, NY, pp. 361-388.

Shermer, M. (2002), Why People Believe Weird Things: Pseudoscience, Superstition, and Other Confusions of Our Time, Freeman, New York, NY.

Slutskaya, N., Simpson, A. and Hughes, J. (2012), "Butchers, quakers and bankrupts: lessons from photo-elicitation", Qualitative Research in Organizations and Management: An International Journal, Vol. 7 No. 1, pp. 16-33.

Smith, G. (2003), "Beyond critical thinking and decision making: teaching business students how to think", Journal of Management Education, Vol. 27 No. 1, pp. 24-51.

Stepanovich, P.L. (2009), "The lobster tale: an exercise in critical thinking”, Journal of Management Education, Vol. 33 No. 6, pp. 725-746.

Taskforce on Active Citizenship (2007), "Report of the Taskforce on Active Citizenship”. Dublin.

Thomas, G.V. and Jolley, R.P. (1984), "Drawing conclusions: a re-examination of empirical and conceptual bases for psychological evaluation of children from their drawings", British Journal of Clinical Psychology, Vol. 37 No. 2, pp. 127-139.

Walsh, J.A. and Sattes, B.D. (2015), Questioning for Classroom Discussion, ASCD, Alexandria, VA.

Waltz, K.N. (1979), Theory of International Relations, McGraw-Hill, Boston, MA.

Warren, S. (2005), "Photography and voice in critical qualitative management research", Accounting, Auditing and Accountability Journal, Vol. 18 No. 6, pp. 861-882.

Weick, K.E. (1993), "The collapse of sensemaking in organisations: the Mann Gulch disaster", Administrative Science Quarterly, Vol. 38 No. 4, pp. 628-652. 
JIEB

13,2

182

Welch, M. (2007), "Identifying and teaching civic engagement skills through service-learning”, in Mac Labhrainn, I. and Mcllrath, L. (Eds), Higher Education and Civic Engagement: International Perspectives, Ashgate, Hampshire, pp. 103-120.

Wilson, B. and Wilson, M. (1987), "Pictorial composition and narrative structure: themes and the creation of meaning in the drawings of Egyptian and Japanese children", Visual Arts Research, Vol. 13 No. 1, pp. 10-21.

Wittmann, B. (2010), "Drawing cure: Children's drawings as a psychoanalytic instrument", Configurations, Vol. 18 No. 3, pp. 251-272.

Wright, S. (2007), "Graphic-narrative play: young children's authoring through drawing and telling", International Journal of Education and the Arts, Vol. 8 No. 1, pp. 1-27.

Zohar, D. (1997), Rewiring the Corporate Brain: Using the New Science to Rethink How We Structure and Lead Organizations, Berrett-Koehler Publishers, San Francisco, CA.

Zuboff, S. (1988), In the Age of the Smart Machine: The Future of Work and Power, Basic Books, New York, NY.

\section{Corresponding author}

Sharon Feeney can be contacted at: sharon.feeney@tudublin.ie

For instructions on how to order reprints of this article, please visit our website: 